\title{
Primer registro de ballena de aleta (Balaenoptera physalus) en el Parque Nacional Natural Corales del Rosario y de San Bernardo, Caribe colombiano
}

\section{First record of a Fin whale (Balaenoptera physalus) in the Rosario and San Bernardo Corals National Natural Park, Colombian Caribbean}

\author{
Natalia Botero-Acosta ${ }^{\prime *}$, Karina Bohrer do Amaral ${ }^{2}$, Dalia C. Barragán-Barrera ${ }^{1,3}$, Nohelia Farías-Curtidor ${ }^{l}$, \\ $\begin{array}{llll}\text { (iD) } 0000-0001-5976-2577 & \text { (D) } 0000-0002-5800-8887 & \text { (D) } 0000-0003-4023-9908 & \text { (D) } 0000-0002-2617-8988\end{array}$
}

Jorge H. Moreno-Sotomayor, ${ }^{4,5}$,Heidys M. Macías-Campo ${ }^{4,5}$, Alejandro Álzate-Montoya y Karla G. Barrientos-Muñoz ${ }^{4,7,8}$ $\begin{array}{llll}\text { (iD) } 0000-0002-7397-9833 & \text { (D) } 0000-0001-8084-6441 & \text { (D) } 0000-0001-6617-0027 & \text { (D) } 0000-0003-3963-5727\end{array}$

1. Fundación Macuáticos Colombia, Medellin, Colombia.macuaticoscolombia@gmail.com*,nofeha@gmail.com

2. Laboratório de Sistemática e Ecologia de Aves e Mamíferos Marinhos (LABSMAR), Instituto de Biociências, Universidade Federal do Rio Grande do Sul, Campus Vale, Porto Alegre (RS), Brasil. karinabohrerdoamaral@gmail.com

3. Centro de Investigaciones Oceanográficas e Hidrográficas del Caribe (CIOH), Dirección General Marítima, Escuela Naval de Cadetes "Almirante

Padilla”, Cartagena de Indias, Colombia. daliac.barraganbarrera@gmail.com

4. Parques Nacionales Naturales de Colombia.

5. Consejo Comunitario de Comunidades Negras del Archipiélago de San Bernardo.puertocaracol2015@gmail.com, heidysmacias08@gmail.com

6. Fundación Sueños de Mar (Fusdem).info@fusdem.org

7. Fundación Tortugas del Mar (FTM).karla.barrientos@udea.edu.co

8. Wider Caribbean Sea Turtle Conservation Network (WIDECAST).

* Autora de correspondencia.

\section{RESUMEN}

$\mathrm{E}$ ntre 23 y 27 de enero de 2020 se registró la presencia de una ballena de aleta (Balaenoptera physalus) en aguas costeras del área marina protegida del Parque Nacional Natural Corales del Rosario y de San Bernardo. Este es el primer registro de un animal vivo para el mar Caribe colombiano. Aunque no fue posible establecer relaciones de causalidad, la presente nota incluye una descripción del contexto ambiental y oceanográfico asociado a los avistamientos. Si bien el Caribe colombiano, por sus características oligotróficas, no soportaría consistentemente la presencia de los grandes rorcuales, se sugiere incluirlo como parte del rango de distribución potencial de la ballena de aleta. El presente registro también resalta la importancia y relevancia de los procesos de ciencia ciudadana y participativa, además del trabajo interinstitucional y colaborativo, acciones clave para el monitoreo de especies de alta movilidad como los mamíferos marinos.

PALABRAS CLAVE: rorcual común, cetáceos, reporte, ciencia ciudadana, Colombia

\section{ABSTRACT}

$\mathrm{B}$ etween January $23^{\text {rd }}$ and $27^{\text {th }}, 2020$, a Fin whale (Balaenoptera physalus) was seen in coastal waters of the Rosario and San Bernardo Corals National Natural Park. This is the first known record of a live animal for the Colombian Caribbean Sea. While it was not possible to establish causality relationships, the present note includes a description of the environmental and oceanographic context associated with sightings. While the Colombian Caribbean, because of its oligotrophy, would not permanently sustain a constant presence of the great baleen whales, its inclusion as part of the potential distribution range for Fin whales is suggested. The current report also highlights the importance and relevance of citizen science, in addition to interinstitutional and collaborative work, key processes for the monitoring of high mobility species such as marine mammals.

KEYWORDS: common rorqual, cetaceans, report, citizen science, Colombia

DOI: https://doi.org/10.25268/bimc.invemar.2020.49.SuplEsp.1092 
La ballena de aleta (Balaenoptera physalus), la segunda especie de mayor talla dentro de la familia Balaenopteridae, es catalogada como de distribución cosmopolita (Aguilar y García-Vernet, 2018). Sin embargo, los registros en la literatura científica evidencian una escasa ocupación de las aguas tropicales (Edwards et al., 2015). Colombia cuenta con tres registros de animales vivos en el océano Pacífico (Vidal, 1990; Palacios et al., 2012). Adicionalmente, los restos óseos de un espécimen proveniente del Caribe estaban depositados en el Museo del Mar de la Universidad Jorge Tadeo Lozano (PrietoRodríguez, 1988).

Entre 23 y 27 de enero de 2020, la comunidad de Puerto Caracol y operadores turísticos del archipiélago de San Bernardo reportaron una ballena cerca a isla Múcura, perteneciente al área marina protegida del Parque Nacional Natural Corales del Rosario y de San Bernardo (PNNCRSB). El PNNCRSB es un área marina protegida bajo la jurisdicción del Distrito Turístico y Cultural de Cartagena de Indias, con una extensión aproximada de 120000 ha (Zarza-González, 2011). Este lugar alberga ecosistemas de considerable biodiversidad entre los que se destacan arrecifes coralinos, manglares, pastos marinos, fondos sedimentarios, bosque seco tropical, lagunas costeras y litorales rocosos y arenosos (Flórez y Etter, 2003; ZarzaGonzález, 2011). La plataforma continental en jurisdicción del PNNCRSB se extiende por aproximadamente $30 \mathrm{~km}$ a partir de la costa y se caracteriza por terrenos planos y paisajes submarinos irregulares con profundidades entre 60 y 110 m (Morales e Idárraga-García, 2013).

El 23 de enero, la comunidad de Puerto Caracol y el equipo de PNNCRSB contaron con el acompañamiento técnico remoto de la Fundación Macuáticos Colombia y la Fundación Tortugas del Mar para organizar un operativo de lanchas que trató de llevar la ballena a aguas abiertas, ya que se ubicaba en una zona de aproximadamente $15 \mathrm{~m}$ de profundidad, lo que representaba riesgo de varamiento. Sin embargo, según lo registrado por los pescadores, la ballena ocupaba con frecuencia aguas someras, presuntamente por la presencia de sardinas. Para el día siguiente, un operador turístico y varios pescadores lograron filmarla. Se apreciaba un nado lento y cercano a la superficie. En el material fílmico también se evidenciaba una distancia considerable entre el espiráculo y la aleta dorsal falcada y ubicada en el último tercio del cuerpo. Adicionalmente, se observaba en el ejemplar una coloración dorsal oscura, casi negra (Figura 1). Desde ese momento, el equipo de PNNCRSB y Guardacostas
Fin whales (Balaenoptera physalus), the second largest species within the Balaenopteridae family, are often considered as having a cosmopolitan distribution (Aguilar and García-Vernet, 2018). Nonetheless, sightings and literature records show a scarce occupation of tropical waters (Edwards et al., 2015). There are only three records of live individuals for Colombia, both from the Pacific Ocean (Vidal, 1990; Palacios et al., 2012). Additionally, the skeleton of a specimen recovered from the Caribbean was kept at the Sea Museum of Jorge Tadeo Lozano University (Prieto-Rodríguez, 1988).

Between January $23^{\text {rd }}$ and $27^{\text {th }}, 2020$, the community of Puerto Caracol along with tourism operators of the San Bernardo Archipelago reported a whale near Múcura Island, within the jurisdiction of the Rosario and San Bernardo Corals National Natural Park (PNNCRSB). PNNCRSB is a marine protected area under the jurisdiction of the Tourism and Culture District of Cartagena with an approximate extension of 120000 ha (Zarza-González, 2011). This area holds ecosystems of considerable biodiversity including coral reefs, seagrasses, sedimentary bottoms, tropical dry forest, coastal lagoons and rocky and sandy coastlines (Flórez and Etter, 2003; Zarza-González, 2011). The continental shelf within the jurisdiction of the PNNCRSB extends over $30 \mathrm{~km}$ from the coastline and is characterized by plain terrains and irregular submarine landscapes with depths that range between 60 and $110 \mathrm{~m}$ (Morales and Idárraga-García, 2013).

On January $23^{\text {rd }}$, the community of Puerto Caracol and personnel from PNNCRSB received technical support from Fundación Macuáticos Colombia and Fundación Tortugas de Mar for the organization of a boat group that tried to drive the whale offshore, since it was occupying waters approximately $15 \mathrm{~m}$ deep, which represented a risk for stranding. Nonetheless, the whale often returned to shallow waters, presumably because of the presence of schools of herring, according to fishermen reports. The next day, a tourism operator and several fishermen managed to film it, where slow traveling near the water surface can be seen. The video also revealed a considerable distance between the blowhole and the dorsal fin, which is falcate and located within the last third of the whale's body. Additionally, a dark coloration, almost black, was also noted (Figure 1). From that moment on, the team at PNNCRSB along with the Coast Guard completed actions of control, vigilance and socialization of the responsible sighting guide for aquatic mammals in Colombia 
desarrollaron trabajos continúo de control, vigilancia y socialización de la guía de avistamiento responsable de mamíferos acuáticos en Colombia (MinAmbiente, 2017) para evitar impactos negativos sobre el animal.

Durante el tercer día consecutivo de avistamiento, los pescadores y el equipo de PNNCRSB registraron la presencia de la ballena en un punto de alta afluencia de sardina. Aunque no fue posible recolectar un espécimen de sardina y, por ello, no pudo identificarse la especie, la sardina común (Sardinella aurita) y el machuelo (Ophistonema oglinum) se sugieren como posibles candidatos. El día 26 de enero miembros de la Fundación Sueños de Mar junto al equipo del PNNCRSB lograron filmar con un dron el desplazamiento superficial y la inmersión aparentemente lenta de la ballena. El video además permitió apreciar la pigmentación asimétrica de la cabeza, con un tono gris claro en la superficie dorsal y blanco hacia la mandíbula inferior, carácter diagnóstico para la ballena de aleta (Balaenoptera physalus) (Aguilar y García-Vernet, 2018; Figura 1). En el marco de este avistamiento fue posible georreferenciar la ubicación del individuo mediante un GPS ( $\left.9^{\circ} 46^{\prime} 22,0^{\prime \prime} \mathrm{N}-75^{\circ} 52^{\prime} 53,3^{\prime \prime} \mathrm{W}\right)$. Finalmente, el 27 de enero de 2020 la ballena solo fue vista en horas de la mañana, a pesar de que el equipo de guardacostas estuvo monitoreando el área en busca de señales que alertaran sobre su presencia.

La ballena fue avistada a un kilómetro de isla Múcura y a $26 \mathrm{~km}$ de la costa (Figura 2). En dicho punto la profundidad se estimó en $82 \mathrm{~m}$ gracias al banco de datos GEBCO (2020), disponible con una resolución de $450 \times 450 \mathrm{~m}$. Adicionalmente y con el fin de contextualizar
(MinAmbiente, 2017) in order to avoid any negative impacts on the animal.

During the third consecutive day of sighting, the fishermen and the team from PNNCRSB reported the whale on waters of herring abundance. While it was not possible to collect a herring specimen, so the species was not identified, the common herring (Sardinella aurita) and the thread herring (Ophistonema oglinum) are suggested as possible candidates. On January $26^{\text {th }}$, members of Fundación Sueños de Mar along with officers from PNNCRSB managed to deploy a drone and film the whale's slow and shallow cruising behavior. The video also allowed the detection of the asymmetrical head pigmentation, with a lighter gray on the dorsal surface and white towards the lower jaw, diagnostic features for Fin whales (Balaenoptera physalus) (Aguilar and García-Vernet, 2018; Figure 1). In the context of this sighting, it was possible to geo-reference the location of the individual with a GPS unit $\left(9^{\circ} 46^{\prime} 22.0^{\prime \prime} \mathrm{N}-75^{\circ} 52^{\prime} 53.3^{\prime \prime} \mathrm{W}\right)$. Finally, on January 27th, 2020, locals only saw the whale in the morning, despite the fact that the Coast Guard was monitoring the area searching for signals that will alert about its presence.

The whale was located one kilometer away from Múcura Island and $26 \mathrm{~km}$ from the coastline (Figure 2). At this point depth was estimated at $82 \mathrm{~m}$ thanks to the GEBCO database (2020), available with a resolution of $450 \times 450 \mathrm{~m}$. Additionally, and in order to contextualize the oceanographic and environmental conditions during the week in which sightings occurred, bathymetry, sea surface temperature, and superficial concentrations of chlorophyll $a$ and particulate

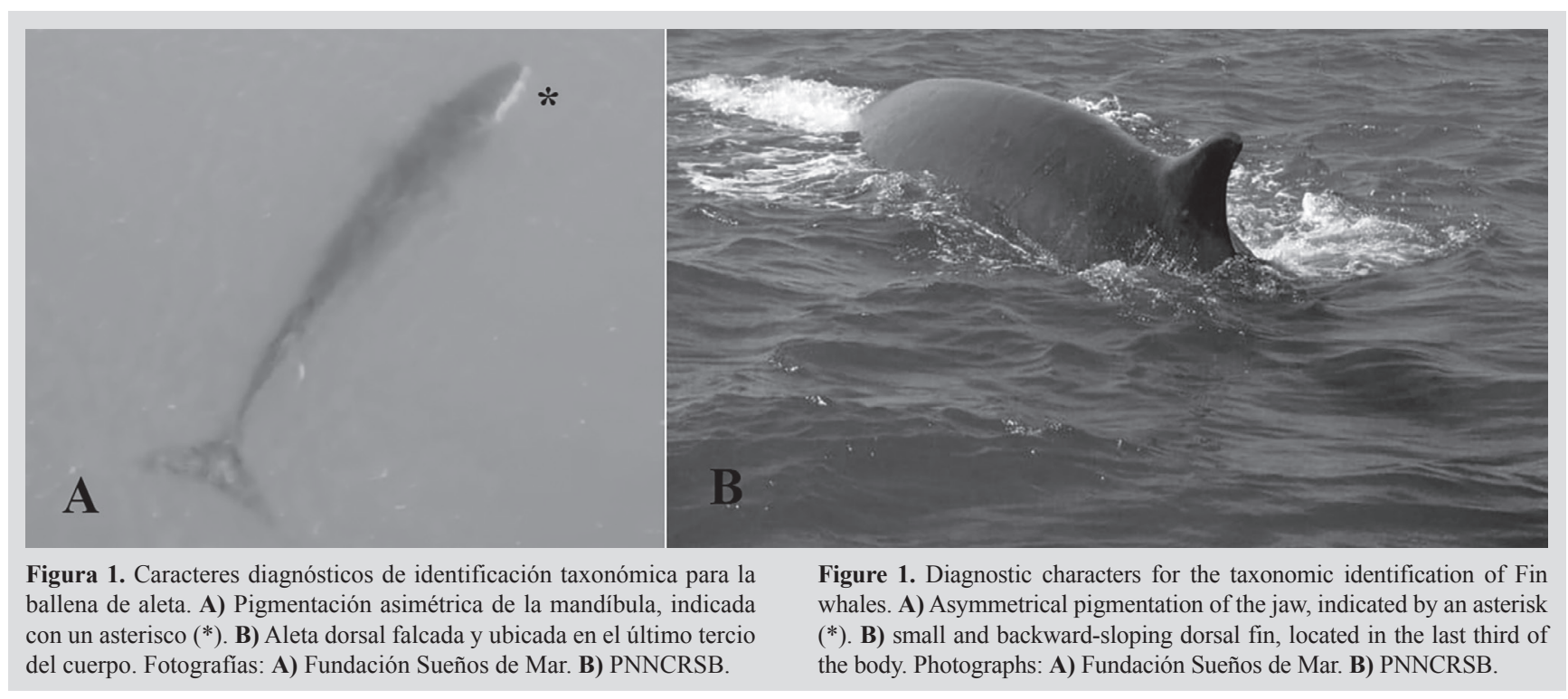


las condiciones oceanográficas durante la semana de los avistamientos, la batimetría y la temperatura superficial del mar, así como las concentraciones superficiales de clorofila $a$ y carbono orgánico particulado fueron estimadas para dos polígonos: uno que abarca el golfo de Morrosquillo, en particular el área de influencia de la desembocadura del río Sinú (Área 1 en la Figura 2) y otro específico en la sección sur del PNNCRSB, alrededor de la ubicación georreferenciada del individuo (Área 2 en la Figura 2). Los datos de concentraciones superficiales de clorofila $a$, carbono orgánico particulado y temperatura superficial del mar fueron consultados con una resolución temporal de ocho días y espacial de $4 \times 4 \mathrm{~km}$ en la plataforma Ocean Color Web (NASA, 2014, 2018a, 2018b) en formato netCDF4. En la porción sur del PNNCRSB, la concentración de clorofila $a$ registrada entre 17 y 24 de enero de 2020 osciló entre 0,2 y $1,21 \mathrm{mg} / \mathrm{m}^{3}$, con un promedio de $0,43 \mathrm{mg} / \mathrm{m}^{3}$. La concentración de carbono orgánico particulado osciló entre 74,8 y $249,8 \mathrm{mg} / \mathrm{m}^{3}$, con un promedio de $133,5 \mathrm{mg} /$ $\mathrm{m}^{3}$. Por su parte, la temperatura superficial del mar osciló entre 28,8 y $29,3{ }^{\circ} \mathrm{C}$, con un promedio de $29^{\circ} \mathrm{C}$. Finalmente, la batimetría osciló entre $-220 \mathrm{~m}$ de profundidad y la línea costera de isla Múcura, con un promedio de $-61 \mathrm{~m}$. Por su parte, para la zona de influencia de la desembocadura del organic carbon were estimated for two polygons: one that included the Gulf of Morrosquillo, and particularly the area of influence of Sinú River mouth (Area 1 within Figure 2) and a second one, which was specific to the southern section of PNNCRSB around the georeferenced location of the individual (Area 2 within Figure 2). Superficial concentrations of chlorophyll $a$, particulated organic carbon and sea surface temperature data were accessed based on an eight day composite and with a spatial resolution of $4 \times 4$ $\mathrm{km}$ through the Ocean Color web platform (NASA 2014, 2018a, 2018b) in netCDF4 format. For the southern section of PNNCRSB, concentration of chlorophyll $a$ reported between January $17^{\text {th }}$ and $24^{\text {th }}, 2020$, ranged between 0.2 and $1.21 \mathrm{mg} / \mathrm{m}^{3}$, with an average of $0.43 \mathrm{mg} / \mathrm{m}^{3}$, while the concentration of particulate organic carbon ranged between 74.8 and $249.8 \mathrm{mg} / \mathrm{m}^{3}$, with an average of 133.5 $\mathrm{mg} / \mathrm{m}^{3}$. Sea surface temperature oscillated between 28.8 and $29.3{ }^{\circ} \mathrm{C}$, with an average of $29{ }^{\circ} \mathrm{C}$. Finally, bathymetry ranged between $-220 \mathrm{~m}$ and the coastline of Múcura Island, with an average of $-61 \mathrm{~m}$. On the other hand, for the zone of influence of the Sinú River mouth, concentration of chlorophyll $a$ reported between January $17^{\text {th }}$ and $25^{\text {th }}$, 2020 , ranged between 0.2 and $5.5 \mathrm{mg} / \mathrm{m}^{3}$, with an average of $1.24 \mathrm{mg} / \mathrm{m}^{3}$, while the concentration of particulated

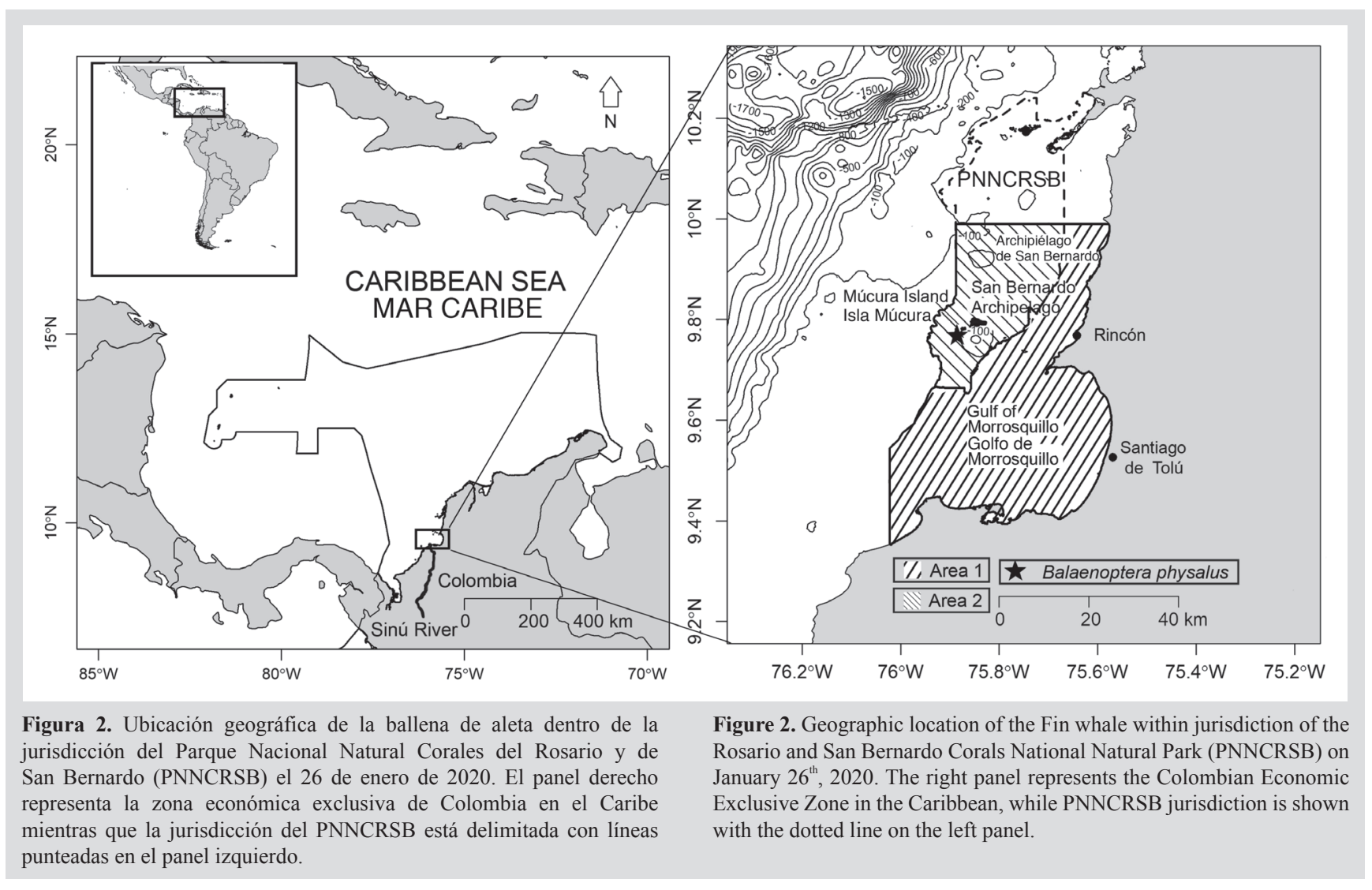


río Sinú, la concentración de clorofila $a$ registrada entre 17 y 24 de enero de 2020 osciló entre 0,2 y $5,5 \mathrm{mg} / \mathrm{m}^{3}$, con un promedio de $1,24 \mathrm{mg} / \mathrm{m}^{3}$. La concentración de carbono orgánico particulado osciló entre 67,6 y 419,4 mg/m³ , con un promedio de $216,5 \mathrm{mg} / \mathrm{m}^{3}$. En adición, la temperatura superficial del mar osciló entre 29,2 y $30,4{ }^{\circ} \mathrm{C}$, con un promedio de $29,6{ }^{\circ} \mathrm{C}$. Finalmente, para esta región, la batimetría osciló entre $-80 \mathrm{~m}$ y la línea costera del golfo de Morrosquillo, con un promedio de $-23 \mathrm{~m}$. El procesamiento de datos ambientales y la extracción de promedios, así como los valores mínimos y máximos para cada polígono fue posible mediante el uso de los paquetes raster (Hijmans, 2017) y rgdal (Bivand et al., 2018) en ambiente R v. 3.5.2 (R Core Team, 2018).

Tradicionalmente, el Caribe colombiano es considerado un ecosistema oligotrófico y homogéneo (Arévalo-Martínez y Franco-Herrera, 2008; Rueda-Roa y Müller-Karger, 2013). Lo anterior, se presume, tiene un impacto considerable sobre la abundancia y diversidad de cetáceos (Barragán-Barrera et al., 2019). Sin embargo, gracias a las descargas de sedimentos de los ríos Amazonas, Orinoco y Sinú, así como a la ocurrencia de surgencias estacionales asociadas a los vientos alisios del norte entre enero y abril, se presentan picos de productividad por año que eventualmente podrían permitir la presencia ocasional de especies como la ballena de aleta, las cuales requieren una gran cantidad de recursos altamente calóricos (RuedaRoa y Müller-Karger, 2013; Aguilar y García-Vernet, 2018).

A pesar de que se ha registrado que las ballenas de aleta se alimentan principalmente de eufáusidos (Mizrock et al., 1984; Tershy, 1992; Aguilar y García-Vernet, 2018), la especie ha mostrado una considerable flexibilidad dietaria, pudiendo explotar cardúmenes de peces de manera oportunística (Kawamura, 1980; Tershy, 1992; Gendron, 1993; Woodley y Gaskin, 1996; Gendron et al., 2001). Aunque no fue posible observar comportamientos de superficie que fueran indicios de alimentación (v. $g$. boca abierta, engolfamiento o distención de los pliegues ventrales), los desplazamientos lentos y superficiales, así como los buceos prolongados han sido sugeridos como posibles indicadores de forrajeo y alimentación (Watkins, 1981; Panigada et al., 2003). Adicionalmente, los recuentos de los pescadores del lugar indicaron de forma consistente la abundancia de sardinas durante los avistamientos, lo cual podría soportar la hipótesis de alimentación oportunística.

El presente registro constituye el primero de un ejemplar vivo de ballena de aleta en el Caribe colombiano. organic carbon ranged between 67.6 and $419.4 \mathrm{mg} / \mathrm{m}^{3}$, with an average of $216.5 \mathrm{mg} / \mathrm{m}^{3}$. In addition, sea surface temperature oscillated between 29.2 and $30.4{ }^{\circ} \mathrm{C}$, with an average of $29.6^{\circ} \mathrm{C}$. Finally, bathymetry ranged between -80 $\mathrm{m}$ and the coastline of the Gulf of Morrosquillo, with an average of $-23 \mathrm{~m}$. Environmental data manipulation and the extraction of averages and minimum/maximum values for each polygon were performed using raster (Hijmans 2017) and rgdal (Bivand et al., 2018) packages implemented in R v. 3.5.2 (R Core Team 2018).

Traditionally, the Colombian Caribbean is considered to be an oligotrophic and homogeneous ecosystem (Arévalo-Martínez and Franco-Herrera, 2008; Rueda-Roa and Müller-Karger, 2013). This, it is presumed, has a considerable impact on cetacean abundance and diversity (Barragán-Barrera et al., 2019). Nonetheless, due to sediment discharge from the Amazon, Orinoco and Sinú rivers, as well as the occurrence of seasonal upwellings associated with the northern trade winds between January and April, there are peaks in productivity per year that could eventually allow the occasional presence of species such as the Fin whale, which require a considerable quantity of highly caloric resources (Rueda-Roa and Müller-Karger, 2013; Aguilar and García-Vernet, 2018).

In spite of reports indicating that euphausiids would be the main prey of Fin whales (Mizrock et al., 1984; Tershy, 1992; Aguilar y García-Vernet, 2018), the species has shown considerable diet flexibility, exploiting school fish in an opportunistic matter (Kawamura, 1980; Tershy, 1992; Gendron, 1993; Woodley and Gaskin, 1996; Gendron et al., 2001). Even though it was not possible to observe surface feeding behavior (e.g. open mouth, engulfment or distension of ventral plates); slow and superficial traveling, as well as prolonged dives, have been suggested as indicators of foraging and feeding (Watkins, 1981; Panigada et al., 2003). In addition, fishermen consistently indicated abundance of herrings during sightings, which could support the hypothesis of opportunistic feeding.

The current report constitutes the first of a living specimen of Fin whale in the Colombian Caribbean. While it has been suggested that the species rarely occupies waters between $20^{\circ} \mathrm{N}$ and $20^{\circ} \mathrm{S}$ (Edwards et al., 2015; Aguilar and García-Vernet, 2018; García-Rivas et al., 2019), which includes the Colombian Caribbean, the sighting near the San Bernardo Archipelago suggests that while such geographic range can include a lower abundance of the species, the waters of the Colombian Caribbean could be part of the 
Si bien se ha sugerido que la especie rara vez ocupa la zona comprendida entre $20^{\circ} \mathrm{N}$ y $20^{\circ} \mathrm{S}$ (Edwards et al., 2015; Aguilar y García-Vernet, 2018; García-Rivas et al., 2019), la cual incluye el Caribe colombiano, el avistamiento en el archipiélago de San Bernardo sugiere que, aunque dicho rango geográfico puede ser de menor abundancia, el Caribe colombiano podría ser parte del ámbito de distribución, al menos secundario, de la ballena de aleta.

Es preciso resaltar la relevancia de los procesos de ciencia ciudadana y participativa, además del trabajo interinstitucional y colaborativo en las instituciones ambientales y científicas, los cuales son vitales para la superación de los vacíos de información (Boney et al., 2009). A la luz del presente registro, es de especial importancia apoyar programas de investigación científica con el propósito de retroalimentar procesos de educación ambiental, particularmente aquellos que prioricen ejercicios de diálogo de saberes.

\section{AGRADECIMIENTOS}

Los autores expresan su agradecimiento a la comunidad de Puerto Caracol en isla Múcura y a localidades aledañas al archipiélago de San Bernardo por su diligencia para con los avistamientos. También agradecen al jefe del PNNCRSB, Teniente de Fragata Edder Libardo Robledo Leal, y al comandante de guardacostas, Capitán de Corbeta David Fernando Rodríguez Barón, por la disposición y acompañamiento en el proceso. La presente publicación no hubiese sido posible sin la colaboración de Martyn Alzate, ya que gracias a sus imágenes se pudo confirmar la identidad taxonómica del individuo. Los autores agradecen igualmente al centro de vuelos espaciales Goddard de la NASA y al grupo de compilación GEBCO por el acceso a los datos de clorofila, temperatura superficial del mar, carbón orgánico particulado y batimetría. Por último, se agradece de forma muy especial al biólogo Christian Bermúdez por su considerable aporte para con la presente nota, así como al Ministerio de Ciencias (Minciencias/Colciencias) por proveer una beca postdoctoral a DCBB a través del Fondo Francisco José de Caldas (convocatoria n. ${ }^{\circ}$ 848) en 2019. distribution range of Fin whales, at least in a secondary way.

It is important to highlight the relevance of citizen and participative science, besides interinstitutional and collaborative work within scientific and environmental institutions, which are vital to overcome information gaps (Boney et al., 2009). Considering the current record, it is particularly important to support programs and initiatives of scientific research in order to provide feedback for environmental education activities within the local communities, particularly those that prioritize knowledge dialogue processes.

\section{ACKNOWLEDGEMENTS}

The authors express their gratitude towards the community of Puerto Caracol at Múcura Island and localities close to the San Bernardo Archipelago for their diligence towards the sightings described here. They also thank the Chief at PNNCRSB, Frigate Lieutenant Edder Libardo Robledo Leal, as well as the Coast Guard Commander Lieutenant David Fernando Rodríguez Barón, for their disposition and company in this process. The current publication could would not have been possible without the collaboration of Martyn Alzate, since thanks to those images it was possible to confirm the taxonomic identity of the individual. The authors would also like to thank NASA's Goddard Space Flight Center and GEBCO Compilation Group, for the access to chlorophyll, sea surface temperature, particulate organic carbon, and bathymetry data. Finally, special thanks to the biologist Christian Bermúdez for his considerable contribution to this note, as well as the Colombian Ministry of Science (Minciencias/ Colciencias) for providing a Postdoctoral Fellowship to DCBB through the Francisco José de Caldas Fund (Call \# 848 ) in 2019. 


\section{BIBLIOGRAFÍA/LITERATURE CITED}

Aguilar, A. and R. García-Vernet. 2018. Fin whale: Balaenoptera physalus. 368-371. En Würsig, B., J.G.M. Thewissen, and K. Kovacs (Eds.). Encyclopedia of marine mammals. Academic Press. 1190 p.

Arévalo-Martínez, D. y A. Franco-Herrera. 2008. Características oceanográficas de la surgencia frente a la ensenada de Gaira, departamento de Magdalena, época seca menor de 2006. Bol. Invest. Mar. Cost. 37(2): 131-162.

Barragán-Barrera, D.C., K.B. Do Amaral, P.A. Chávez-Carreño, N. Farías-Curtidor, R. Lancheros-Neva, N. Botero-Acosta, et al. 2019. Ecological niche modeling of three species of Stenella dolphins in the Caribbean Basin, with application to the Seaflower Biosphere Reserve. Front. Mar. Sci., 6: 1-17.

Bivand, R., T. Keitt, and B. Rowlingson. 2018. rgdal: bindings for the 'geospatial' data Abstraction Library. R package version 1.3-6. https://CRAN.Rproject.org/package $=$ rgdal

Bonney, R., C.B. Cooper, J. Dickinson, S. Kelling, T. Phillips, K.V. Rosenberg, and J. Shirk. 2009. Citizen science: a developing tool for expanding science knowledge and scientific literacy. BioScience, 59: 977-984.

Edwards, E.F., C. Hall, T.J. Moore, C. Sheredy, and J.V. Redfern. 2015. Global distribution of Fin whales Balaenoptera physalus in the post $\square$ whaling era (1980-2012). Mamm. Rev., 45: 197-214.

Flórez, C. y A. Etter. 2003. Caracterización ecológica de las islas Múcura y Tintipán, archipiélago de San Bernardo, Colombia. Rev. Acad. Colomb. Cienc., 27: 343-356.

García-Rivas, M.C., M.P. Blanco-Parra, D.N. Castelblanco-Martínez, and C.A. Niño-Torres. 2019. First record of a Fin whale Balaenoptera physalus in the Mexican Caribbean. Hidrobiológica, 29: 41-43.

GEBCO Compilation Group. 2020. GEBCO 2020 Grid. https://doi.org/10.5285/a29c5465-b138-234d-e053-6c86abc040b9. 11/09/2020.

Gendron, D. 1993. Índice de avistamiento y distribución del género Balaenoptera en el golfo de California, México, durante febrero, marzo y abril 1988. Rev. Inv. Cient. 1: 21-30.

Gendron, D., S. Aguíñiga, and J.D. Carriquiry. 2001. $\mathrm{d}^{15} \mathrm{~N}$ and $\mathrm{d}^{13} \mathrm{C}$ in skin biopsy samples: a note on their applicability for examining the relative trophic level in three rorqual species. J. Cetacean Res. Manag., 3: 41-44.

Hijmans, R. 2017. raster: geographic data analysis and modeling. R package version 2.6-7. https://CRAN.R-project.org/package=raster

Kawamura, A. 1980. A review of food of balaenopterid whales. Sci. Rep. Whales Res. Inst. 32: 155-197.

Ministerio de Ambiente y Desarrollo Sostenible. 2017. Guía de avistamiento responsable de mamíferos acuáticos en Colombia.

https://www.minambiente.gov.co/images/NegociosVerdesysostenible/pdf/boletines/AVISTAMIENTOS_48_PAG_baja.pdf. 01/08/2020.

Mizroch, S.A., D.W. Rice, and J.M. Breiwick. 1984. The Fin whale, Balaenoptera physalus. Mar. Fish. Rev., 46: 20-24.

Morales, D. F. y J. Idárraga-García. 2013. Caracterización de los subfondos marinos del Parque Nacional Natural Corales del Rosario y San Bernardo (PNNCRSB), Colombia. Invemar, Santa Marta. https://doi.org/10.13140/2.1.1971.2007

NASA Goddard Space Flight Center, Ocean Ecology Laboratory, Ocean Biology Processing Group. Moderate-resolution Imaging Spectroradiometer (MODIS) Aqua $11 \mu \mathrm{m}$ Day/Night Sea Surface Temperature Data. 2014. NASA OB.DAAC, Greenbelt, USA.

NASA Goddard Space Flight Center, Ocean Ecology Laboratory, Ocean Biology Processing Group. Moderate-resolution Imaging Spectroradiometer (MODIS) Aqua Chlorophyll Data. 2018a. NASA OB.DAAC, Greenbelt, USA. https://oceancolor.gsfc.nasa.gov/data/10.5067/AQUA/MODIS/L3B/ CHL/2018. 11/09/2020.

NASA Goddard Space Flight Center, Ocean Ecology Laboratory, Ocean Biology Processing Group. Moderate-resolution Imaging Spectroradiometer (MODIS) Aqua Particulate Organic Carbon Data. 2018b. NASA OB.DAAC, Greenbelt, USA. https://oceancolor.gsfc.nasa.gov/data/10.5067/AQUA/ MODIS/L3M/POC/2018. 10/31/2020.

Palacios, D.M, J.C. Herrera, T. Gerrodette, C. García, G.A. Soler, I.C. Ávila, S. Bessudo, E. Hernández, F. Trujillo, L. Flórez-González, and I. Kerr. 2012. Cetacean distribution and relative abundance in Colombia's Pacific EEZ from survey cruises and platforms of opportunity. J. Cetacean Res. Manag., 12: $45-60$.

Panigada, S., G. Pesante, M. Zanardelli, and S. Oehen. 2003. Day and night-time diving behavior of Fin whales in the western Ligurian Sea. https://doi. org/10.1109/OCEANS.2003.178624

Prieto Rodríguez, M. 1988. Reporte de algunos cetáceos del Caribe colombiano. Bol. Fac. Biol. Mar., 8: 30-40.

R Core Team. 2018. R: a language and environment for statistical computing. Vienna: R Foundation for Statistical Computing. https://www.R-project.org/ 
Rueda-Roa, D.T. and F.E. Müller-Karger. 2013. The southern Caribbean upwelling system: sea surface temperature, wind forcing and chlorophyll concentration patterns. Deep Sea Res. Part I: Oceanogr. Res. Pap. 78: 102-114.

Rueda-Roa, D.T., T. Ezer, and F.E. Müller-Karger. 2018. Descriptions and mechanisms of the mid-year upwelling in the southern Caribbean Sea from remote sensing and local data. J. Mar. Sci. Eng., 6: 1-19.

Tershy, B.R. 1992. Body size, diet, habitat use, and social behavior of Balaenoptera whales in the Gulf of California. J. Mammal., 73(3): 477-486.

Vidal, O. 1990. Lista de los mamíferos acuáticos de Colombia. Inf. Mus. Mar, 37: 1-18.

Watkins, W.A. 1981. Activities and underwater sounds of Fin whales. Sci. Rep. Whales Res. Inst., 33: 83-117.

Woodley, T.H. and D.E. Gaskin. 1996. Environmental characteristics of North Atlantic right and Fin whale habitat in the lower Bay of Fundy, Canada. Can. J. Zool., 74: 75-84.

Zarza-González, E. 2011. El entorno ambiental del Parque Nacional Natural Corales del Rosario y de San Bernardo. Cartagena de Indias, Colombia. 416 p. 